\title{
Comparison of the xylose reductase-xylitol dehydrogenase and the xylose isomerase pathways for xylose fermentation by recombinant Saccharomyces cerevisiae
}

\author{
Kaisa Karhumaa, Rosa Garcia Sanchez, Bärbel Hahn-Hägerdal and Marie- \\ F Gorwa-Grauslund*
}

Address: Department of Applied Microbiology, Lund University, P.O.Box 124, SE-22100 Lund, Sweden

Email: Kaisa Karhumaa - kaisa.karhumaa@tmb.lth.se; Rosa Garcia Sanchez - Rosa.Garcia_Sanchez@tmb.lth.se; Bärbel HahnHägerdal - Barbel.Hahn-Hagerdal@tmb.lth.se; Marie-F Gorwa-Grauslund* - Marie-Francoise.Gorwa@tmb.lth.se

* Corresponding author

Published: 5 February 2007

Microbial Cell Factories 2007, 6:5 doi:10.1 186/1475-2859-6-5
Received: 5 December 2006

Accepted: 5 February 2007

This article is available from: http://www.microbialcellfactories.com/content/6/1/5

(C) 2007 Karhumaa et al; licensee BioMed Central Ltd.

This is an Open Access article distributed under the terms of the Creative Commons Attribution License (http://creativecommons.org/licenses/by/2.0), which permits unrestricted use, distribution, and reproduction in any medium, provided the original work is properly cited.

\begin{abstract}
Background: Two heterologous pathways have been used to construct recombinant xylosefermenting Saccharomyces cerevisiae strains: i) the xylose reductase (XR) and xylitol dehydrogenase $(\mathrm{XDH})$ pathway and ii) the xylose isomerase (XI) pathway. In the present study, the Pichia stipitis $\mathrm{XR}-\mathrm{XDH}$ pathway and the Piromyces XI pathway were compared in an isogenic strain background, using a laboratory host strain with genetic modifications known to improve xylose fermentation (overexpressed xylulokinase, overexpressed non-oxidative pentose phosphate pathway and deletion of the aldose reductase gene GRE3). The two isogenic strains and the industrial xylosefermenting strain TMB 3400 were studied regarding their xylose fermentation capacity in defined mineral medium and in undetoxified lignocellulosic hydrolysate.
\end{abstract}

Results: In defined mineral medium, the xylose consumption rate, the specific ethanol productivity, and the final ethanol concentration were significantly higher in the XR- and XDHcarrying strain, whereas the highest ethanol yield was achieved with the strain carrying XI. While the laboratory strains only fermented a minor fraction of glucose in the undetoxified lignocellulose hydrolysate, the industrial strain TMB 3400 fermented nearly all the sugar available. Xylitol was formed by the XR-XDH-carrying strains only in mineral medium, whereas in lignocellulose hydrolysate no xylitol formation was detected.

Conclusion: Despite by-product formation, the XR-XDH xylose utilization pathway resulted in faster ethanol production than using the best presently reported XI pathway in the strain background investigated. The need for robust industrial yeast strains for fermentation of undetoxified spruce hydrolysates was also confirmed.

\section{Background}

Saccharomyces cerevisiae is a promising candidate for industrial bioethanol production due to its robustness, inhibitor tolerance and high ethanol productivity $[1,2]$.
Efficient fermentation of pentose sugars is necessary to attain economically feasible processes for ethanol production from lignocellulosic biomass [3], however S. cerevisiae does not naturally ferment xylose. Anaerobic xylose 
fermentation by $S$. cerevisiae was first demonstrated by heterologous expression of xylose reductase (XR) and xylitol dehydrogenase (XDH) [4] from Pichia stipitis together with overexpression of the endogenous xylulokinase (XK) [5-8]. However, the difference in cofactor preference between the mainly NADPH-dependent XR and the strictly $\mathrm{NAD}^{+}$-dependent XDH may limit the flux from xylose to xylulose (Figure 1A), which has been supported by xylitol excretion observed in strains carrying XR and $\mathrm{XDH}$ [6-11]. Later, xylitol excretion has been reduced by metabolic engineering strategies such as optimisation of the expression levels of XR and XDH [12-15], changing the cofactor affinity of XR [16], or modifying the redox metabolism of the host cell [17-19].

To instead allow isomerization of xylose to xylulose (Figure 1B), heterologous expression of several xylose isomerases (XI) in S. cerevisiae has been attempted [20-26], of which the XI from the fungus Piromyces sp. [26] resulted in the highest activity. However, the sole expression of Piromyces XI did not result in appreciable growth on xylose [26]. Only when adaptation [27] or extensive genetic engineering [28] was also applied, were growth and fermentation on xylose achieved.

Genetic modifications other than the sole introduction of initial xylose utilization pathway are needed for efficient xylose metabolism. The combination of overexpressed $\mathrm{XK}$, overexpressed non-oxidative pentose phosphate path-

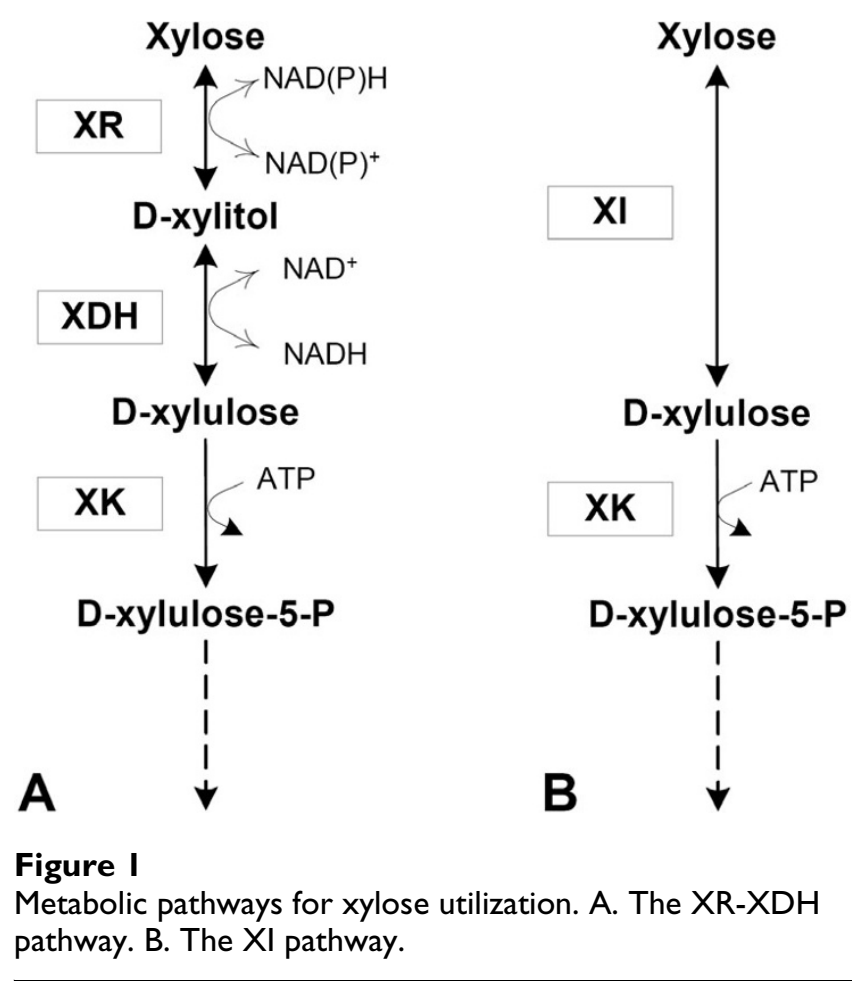

way (PPP) and deletion of the endogenous aldose reductase gene GRE3 have been shown to enhance both aerobic and anaerobic xylose utilization in XR-XDH- as well as XIcarrying strains $[15,28,29]$. The overexpression of XK is necessary to overcome the naturally low expression level of this enzyme $[6,8,30,31]$, and the overexpression of the PPP enzymes enables efficient incorporation of xylulose5-phosphate into the central metabolism [32]. Furthermore, the gene GRE3 codes for an unspecific reductase that functions as an NADPH-dependent xylose reductase [33], and contributes to xylitol formation [34,35] with concomitant inhibition of XI activity [36].

To the best of our knowledge, no comparative assessment has been reported for a pair of isogenic strains with the two functional xylose utilization pathways, XR and XDH from P. stipitis, or XI from Piromyces sp. In the present study, an engineered strain with overexpressed XK, overexpressed non-oxidative PPP and GRE3 deletion in CEN.PK background was used [29] to generate two isogenic strains that carried either the XR-XDH or the XI pathway. The xylose fermentation performance of the two strains was compared.

Recombinant xylose-fermenting strains are aimed to be used in industrial ethanol production from lignocellulose hydrolysates. The hydrolysates contain large amounts of inhibitory compounds such as furfural, hydroxymethyl furfural, acetate and phenolics, the concentrations of which depend on the raw material and hydrolysis method [37-39]. As industrial yeast strains are generally more tolerant to such inhibitors than laboratory strains [40,41], the two isogenic strains were also compared with the industrial xylose-fermenting strain TMB 3400 [42] with respect to hexose and pentose fermentation in an undetoxified lignocellulose hydrolysate.

\section{Results \\ Strain construction}

To generate an isogenic pair of strains, a strain with highlevel expression of XI was constructed similar to the previously generated strain TMB 3057 with high-level expression of XR and XDH [29] (Table 1). The strain background TMB 3044, which contains overexpressed XK, overexpressed non-oxidative PPP and deletion of the aldose reductase gene GRE3 [29] (Table 1), was used. The Piromyces XI gene was cloned in the yeast multicopy plasmid YEplacHXT [29] between the truncated HXT7 promoter [43] and the PGK1 terminator. The truncated HXT7 promoter has been reported to give the highest expression levels compared with other yeast glycolytic promoters [43]. The plasmid containing the XI gene was then used to transform strain TMB 3044 [29], resulting in strain TMB 3066 (Table 1). Thus, strain TMB 3066, with high XI activity, and strain TMB 3057, with high XR and XDH activi- 
Table I: Strains and plasmids used in this study.

\begin{tabular}{|c|c|c|c|}
\hline & Relevant genotype & $\begin{array}{l}\text { Xylose } \\
\text { pathway }\end{array}$ & Reference \\
\hline \multicolumn{4}{|l|}{ Plasmids } \\
\hline YEplacHXT & bla HXT7p-PGKIt URA3 & - & [29] \\
\hline $\begin{array}{l}\text { YEpHXT-XIp } \\
\text { S. cerevisiae }\end{array}$ & bla HXT7p-XI (Piromyces)-PGKIt URA3 & $\mathrm{XI}$ & This study \\
\hline TMB 3044 & $\begin{array}{l}\text { CEN.PK 2-IC, } \triangle \text { gre3, his3:::PGKIp-XKSI-PGKIt, TALI ::PGKIp-TALI-PGKIt, TKLI ::PGKIp-TKLI-PGKIt, } \\
\text { RKII::PGKIp-RKII-PGKIt, RPEI::PGKIp-RPEI-PGKIt, }\end{array}$ & - & [29] \\
\hline TMB 3057 & TMB 3044, pY7 (ADHIp-XYLI-ADH2t, PGKIp-XYL2-PGKIt URA3) & XR-XDH-XK & [29] \\
\hline TMB 3066 & TMB 3044, YEpHXT-XIp (HXT7p-XI-PGKIt URA3) & $\mathrm{XI}-\mathrm{XK}$ & This study \\
\hline TMB 3400 & HIS3::(ADHIp-XYLI-ADH2t, PGKIp-XYL2-PGKIt, PGKIp-XKSI-PGKIt) & XR-XDH-XK & {$[42]$} \\
\hline
\end{tabular}

ties, are isogenic with the exception of the plasmids containing the two xylose-utilization pathways.

Strain TMB 3066 with XI grew aerobically on xylose at a growth rate of $0.02 \mathrm{~h}^{-1}$, whereas a growth rate of $0.16 \mathrm{~h}^{-1}$ has previously been obtained for strain TMB 3057 with XR and XDH under same conditions [29] (Figure 2). Anaerobic growth was not measured. XI activity in strain TMB 3066 was $0.82 \pm 0.01 \mathrm{U} / \mathrm{mg}$ protein.

\section{Anaerobic xylose fermentation in mineral medium}

Xylose fermentation by strains TMB 3057 and TMB 3066 was compared in anaerobic batch culture. The industrial strain TMB 3400 with chromosomally integrated XR-XDH genes [42] was also included in the comparison. Buffered mineral medium containing xylose $(50 \mathrm{~g} / \mathrm{l})$ and an initial biomass concentration of $5 \mathrm{~g}$ dry weight/l were used. Representative fermentation profiles for the three strains are shown in Figure 3.

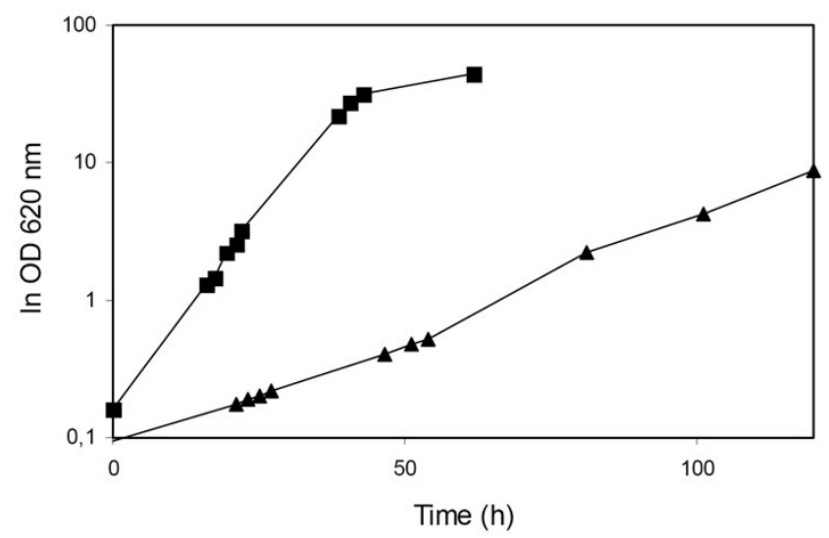

Figure 2

Aerobic growth of TMB 3057 (XR-XDH) ( $\square$ ) and TMB 3066 $(\mathrm{XI})(\boldsymbol{\Delta})$ in mineral medium with xylose $(50 \mathrm{~g} / \mathrm{l})$ as the sole carbon source.
The XR-XDH-carrying strain TMB 3057 consumed xylose at a rate of $0.13 \mathrm{~g}$ xylose $\mathrm{g}$ cells ${ }^{-1} \mathrm{~h}^{-1}$ (Table 2 ), with ethanol, xylitol and glycerol as fermentation products (Figure 3A). The isogenic strain TMB 3066 carrying XI consumed

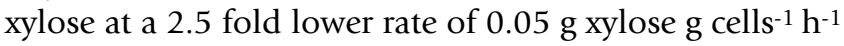
(Table 2). Ethanol was the major fermentation product of TMB 3066 (Figure 3B), with a yield of $0.43 \mathrm{~g}$ g consumed xylose $^{-1}$, which is close to the theoretical yield of $0.51 \mathrm{~g} \mathrm{~g}$ consumed xylose ${ }^{-1}$ (Table 2). Despite the formation of the by-products, TMB 3057 produced twice as much ethanol $(13.3 \mathrm{~g} / \mathrm{l})$ within 50 hours as a result of the higher xylose consumption rate. The specific ethanol productivity was 2-fold higher in the XR-XDH-carrying strain TMB 3057 than in the XI-carrying strain TMB 3066 (Table 2). The industrial strain TMB 3400 consumed xylose more slowly than the laboratory strain TMB 3057 (Table 2) (Figure 3C).

\section{Fermentation of lignocellulose hydrolysate}

The three strains studied were also compared in batch fermentation of an undetoxified spruce hydrolysate [44]. The initial concentrations of the hydrolysate components were as follows: glucose, $16 \mathrm{~g} / \mathrm{l}$; mannose, $10 \mathrm{~g} / \mathrm{l}$; galactose, $4 \mathrm{~g} / \mathrm{l}$; xylose, $7 \mathrm{~g} / \mathrm{l}$; arabinose, $3 \mathrm{~g} / \mathrm{l}$; and acetic acid, $2.5 \mathrm{~g} / \mathrm{l}$. Fermentation was started with an initial biomass concentration of 5-10 g dry weight/l and pH 5.5. Representative fermentation profiles are shown in Figure 4, and the fermentation parameters are summarized in Table 3.

Only a small amount of glucose was consumed by the two laboratory strains (Figures 4A, 4B), whereas nearly all glucose, mannose and xylose were consumed by the industrial strain TMB 3400 (Figure 4C). The final ethanol concentration was about $3 \mathrm{~g} / \mathrm{l}$ for TMB 3057 (XR-XDH), 2 $\mathrm{g} / \mathrm{l}$ for TMB 3066 (XI), and $16 \mathrm{~g} / \mathrm{l}$ for the strain TMB 3400 (the XR-XDH-carrying industrial strain) (Figure 4). No xylitol was produced by TMB 3400, although nearly all the xylose was consumed within $100 \mathrm{~h}$ (Figure 4C). 

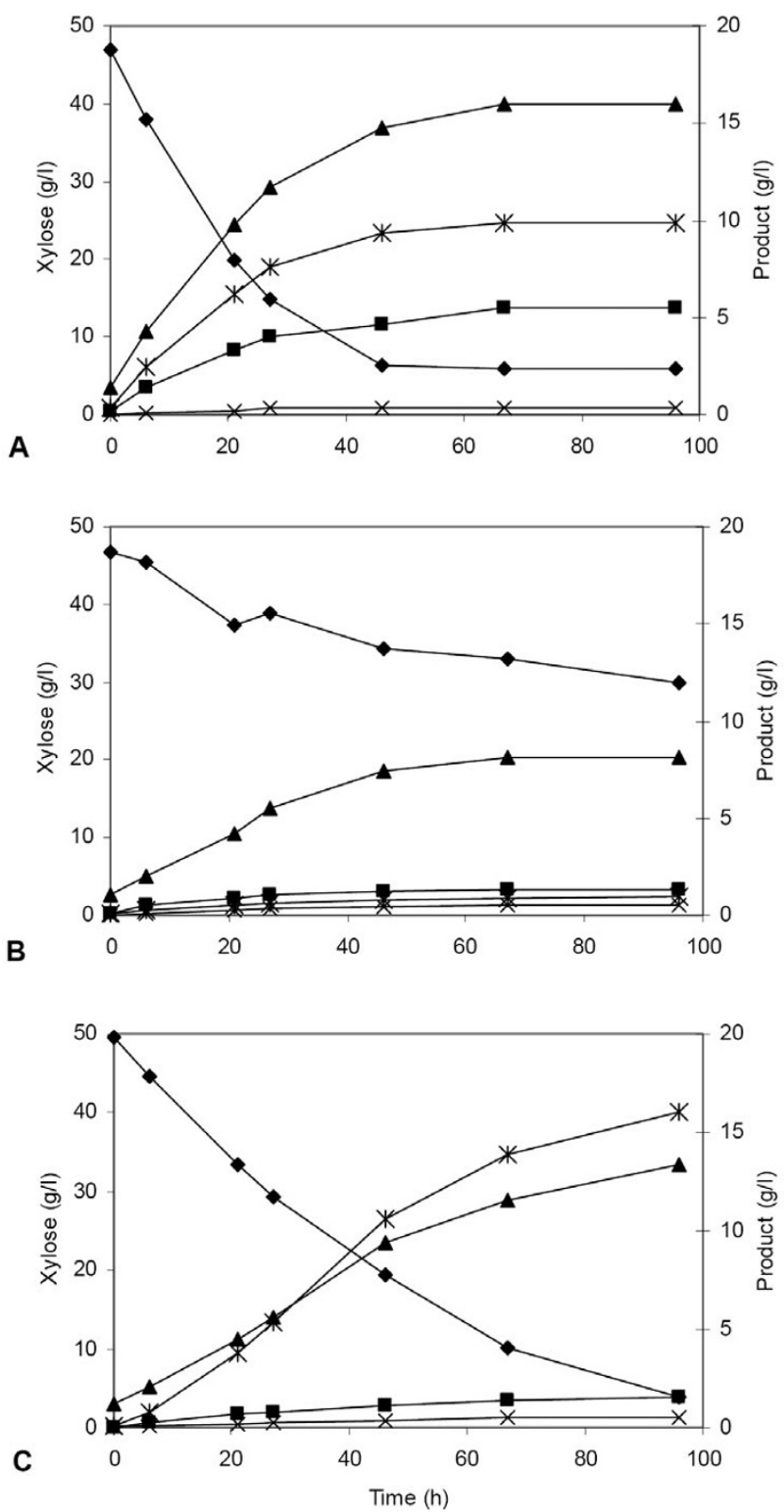

Figure 3

Anaerobic fermentation profiles of strains TMB 3057 (P. stipitis $\mathrm{XR}$ and $\mathrm{XDH}$ on plasmid) (A), TMB 3066 (Piromyces $\mathrm{XI}$ on plasmid) (B) and TMB 3400 (industrial strain with chromosomally integrated $P$. stipitis $X R$ and $X D H)(C)$. Mineral medium with xylose $(50 \mathrm{~g} / \mathrm{l})$ was used. The initial biomass concentration for all strains was $5 \mathrm{~g} / \mathrm{l}$. Symbols: $\downarrow$ xylose; $*$ xylitol; $\mathbf{\square}$ glycerol; $\boldsymbol{\Delta}$ ethanol; $\times$ acetate.

\section{Discussion}

Isogenic strains were used to compare the efficiency of xylose fermentation via the $P$. stipitis $\mathrm{XR}$ and $\mathrm{XDH}$ route and the Piromyces XI route. Comparing the two pathways in isogenic strains eliminates the influence of strain background on xylose uptake rate and product formation. In anaerobic batch fermentation of xylose in mineral medium, the xylose consumption rate was higher in the XR-XDH-carrying strain TMB 3057 than in the XI-carrying TMB 3066 in the strain background used. However, the XI-carrying strain TMB 3066 produced ethanol at almost theoretical yield. Nevertheless, TMB 3057 produced twice as much ethanol due to faster and almost complete xylose consumption. This is in accordance with the 8-fold higher aerobic growth rate that was observed on xylose for the XR-XDH-carrying strain (Figure 2).

The XI-carrying strain TMB 3066 reported in the present study displayed slower aerobic growth on xylose and slower anaerobic xylose fermentation than the previously designed strain RWB217 [28] (Table 4) with identical reported genetic modifications. The aerobic growth rate of TMB 3066 on xylose was $0.02 \mathrm{~h}^{-1}$, compared to $0.22 \mathrm{~h}^{-1}$ measured for strain RWB217 in the previous investigation [28]. The slower xylose utilization of TMB 3066 cannot be attributed to a lower XI level, since the XI activity (0.82 U $\mathrm{mg}_{\text {protein }}{ }^{-1}$ ) was in the same range as that of the previously reported strain (0.3-1.1 U mg protein ${ }^{-1}$ ) [26] (Table $4)$. Thus, the reason for the slower growth and fermentation of the XI-carrying strain TMB 3066 in the present study probably lies in the strain background. Both strains originate from a CEN.PK laboratory strain and nearly identical genetic modifications were made [29]. This suggests that the xylose fermentation capacity of the RWB217 must be ascribed to unknown strain characteristics. For example, this may result from higher activity levels of XK or the PPP enzymes in RWB217 than in TMB 3057, that could have originated from mutagenic events during the transformation process. While the activities of XK and the PPP enzymes have been reported for TMB 3057 [29], this information is not available for RWB217 [28] (Table 4).

The comparison of xylose fermentation with the isogenic strains demonstrates that the Piromyces XI activity is not sufficient to ensure the same growth and fermentation rates as those obtained with the XR-XDH pathway in the strain background investigated. Highest possible XI activity among the presently known XI genes was used, since the Piromyces XI gene was expressed on a multicopy plasmid from the strongest known yeast promoter [43]. When the XI gene was chromosomally integrated in the same strain background that was used for constructing TMB 3057 and TMB 3066, aerobic growth on xylose was not achieved (data not shown). However, chromosomal integration is a prerequisite to render industrial production organisms genetic stability [45], and this can not be obtained with multicopy plasmid-carrying strains [46,47]. As opposed to XI, chromosomal integration of XR and $\mathrm{XDH}$ in industrial strain background is sufficient to ena- 
Table 2: Results of anaerobic batch fermentation of xylose (50 g/l) by strains TMB 3057, TMB 3066 and TMB 3400.

\begin{tabular}{|c|c|c|c|c|c|c|c|c|}
\hline \multirow[b]{2}{*}{ Strain } & \multirow[b]{2}{*}{$\begin{array}{l}\text { Relevant } \\
\text { genotype }\end{array}$} & \multirow[b]{2}{*}{$\begin{array}{l}\text { Xylose } \\
\text { consumed } \\
\text { in } 100 \mathrm{~h}\end{array}$} & \multirow[b]{2}{*}{$\begin{array}{l}\text { Final ethanol } \\
\text { concentration }\end{array}$} & \multirow[b]{2}{*}{$\begin{array}{l}\text { Specific xylose } \\
\text { consumption } \\
\text { rate }\end{array}$} & \multirow[b]{2}{*}{$\begin{array}{l}\text { Specific ethanol } \\
\text { productivity }\end{array}$} & \multicolumn{3}{|c|}{ Yield } \\
\hline & & & & & & Ethanol & Xylitol & Glycerol \\
\hline & & $\mathrm{gl}^{-1}$ & $\mathrm{gl}^{-1}$ & $\begin{array}{l}\text { g xylose g } \\
\text { cells }{ }^{-1} \mathrm{~h}^{-1}\end{array}$ & $\begin{array}{l}g \text { ethanol } \\
g \text { cells } s^{-1} h^{-1}\end{array}$ & $\begin{array}{c}\text { g g consumed } \\
\text { xylose } \mathrm{e}^{-1}\end{array}$ & $\begin{array}{c}\text { gg consumed } \\
\text { xylose }^{-1}\end{array}$ & $\begin{array}{c}\text { gg consumed } \\
\text { xylose }^{-1}\end{array}$ \\
\hline TMB 3057 & $\begin{array}{l}\mathrm{XR}-\mathrm{XDH}, \\
\text { plasmid }\end{array}$ & $39.6 \pm 3.4$ & $13.3 \pm 1.7$ & $0.13 \pm 0.04$ & $0.04 \pm 0.01$ & $0.33 \pm 0.02$ & $0.22 \pm 0.03$ & $0.11 \pm 0.02$ \\
\hline TMB 3066 & $\begin{array}{c}\text { XI, } \\
\text { plasmid }\end{array}$ & $16.8 \pm 3.8$ & $7.3 \pm 2.1$ & $0.05 \pm 0.02$ & $0.02 \pm 0.01$ & $0.43 \pm 0.03$ & $0.04 \pm 0.02$ & $0.07 \pm 0.02$ \\
\hline TMB 3400 & $\begin{array}{l}\text { XR-XDH, } \\
\text { integrated }\end{array}$ & $36.5 \pm 10.8$ & $12.1 \pm 2.5$ & $0.06 \pm 0.02$ & $0.02 \pm 0.01$ & $0.34 \pm 0.03$ & $0.29 \pm 0.07$ & $0.04 \pm 0.01$ \\
\hline
\end{tabular}

ble xylose fermentation in lignocellulose hydrolysates, as demonstrated for strain TMB $3400[48,49]$ (Figure 4).

The difference in xylose consumption between the XR$\mathrm{XDH}-$ and XI-carrying isogenic strains may be partly explained by the kinetic properties of the enzymes involved. The $\mathrm{K}_{\mathrm{m}}$ of the Piromyces XI for xylose has been estimated to about $20 \mathrm{mM}$ [26], while the $\mathrm{K}_{\mathrm{m}}$ of the $P$. stipitis XR for xylose ranges from $42 \mathrm{mM}$ [50] to $97 \mathrm{mM}$ [51]. No other kinetic information is available for the Piromyces XI. The specific activity of purified bacterial XIs ranges from 2 to $20 \mathrm{U} \mathrm{mg} \mathrm{protein}^{-1}$ [52], while for $P$. stipitis $\mathrm{XR}$ it is $17-48 \mathrm{U} \mathrm{mg}$ protein $^{-1}[50,51]$. Although the Piromyces XI has a slightly higher affinity for xylose, the higher specific activity of XR may result in more efficient in vivo conversion of xylose to xylitol, and thereafter to xylulose. A XI with higher specific activity and improved kinetic properties could be generated by mutagenesis [53] or gene shuffling [54], in combination with an efficient screening strain [29] to allow faster xylose utilization and chromosomal integration.

The industrial strain TMB 3400 with chromosomally integrated XR and XDH genes [42] was included in the present comparison because it ferments xylose in both mineral medium [41] and in undetoxified lignocellulose hydrolysate [48]. In mineral medium TMB 3400 consumed xylose more slowly and produced more xylitol than TMB 3057, most likely due to the lower XR and XDH levels $[15,55]$ resulting from chromosomal integration of the XR and $\mathrm{XDH}$ genes, compared with plasmid-based expression in TMB 3057.

Because the design of xylose-fermenting strains for bioethanol production aims at fermentation of industrial substrates, the three strains TMB 3057 (XR-XDH), TMB 3066 (XI) and TMB 3400 (integrated XR-XDH) were also compared regarding the fermentation of an undetoxified spruce hydrolysate. Laboratory strains are considered to

Table 3: Results of anaerobic batch fermentation of undetoxified lignocellulose hydrolysate by strains TMB 3057 , TMB 3066 and TMB 3400.

\begin{tabular}{|c|c|c|c|c|c|c|c|c|}
\hline \multirow[b]{2}{*}{ Strain } & \multirow[b]{2}{*}{$\begin{array}{l}\text { Relevant } \\
\text { genotype }\end{array}$} & \multirow[b]{2}{*}{$\begin{array}{c}\text { Glucose } \\
\text { consumptio } \\
\text { n rate }\end{array}$} & \multirow[b]{2}{*}{$\begin{array}{c}\text { Mannose } \\
\text { consumption } \\
\text { rate }\end{array}$} & \multirow[b]{2}{*}{$\begin{array}{c}\text { Xylose } \\
\text { consumption } \\
\text { rate }\end{array}$} & \multirow[b]{2}{*}{$\begin{array}{c}\text { Specific } \\
\text { ethanol } \\
\text { productivity }\end{array}$} & \multicolumn{3}{|c|}{ Yield } \\
\hline & & & & & & Ethanol & Glycerol & Xylitol \\
\hline & & $\begin{array}{l}\text { g glucose g } \\
\text { cells-1 } \mathrm{h}^{-1}\end{array}$ & $\begin{array}{l}g \text { mannose } g \\
\text { cells } s^{-1} h^{-1}\end{array}$ & $\begin{array}{c}\text { g xylose g cells- } \\
1 \mathrm{~h}^{-1}\end{array}$ & $\begin{array}{l}\mathrm{g} \text { ethanol } \mathrm{g} \\
\text { cells } \mathrm{s}^{-1} \mathrm{~h}^{-1}\end{array}$ & $\begin{array}{l}\text { g g total } \\
\text { sugar }-1\end{array}$ & $\begin{array}{l}\text { g g total } \\
\text { sugar-1 }\end{array}$ & g g xylose-1 \\
\hline TMB 3057 & $\begin{array}{l}\text { XR-XDH, } \\
\text { laboratory } \\
\text { strain }\end{array}$ & $0.008 \pm 0.003$ & 0 & 0 & $0.005 \pm 0.002$ & $0.08 \pm 0.02$ & $0.006 \pm 0.001$ & 0 \\
\hline TMB 3066 & $\begin{array}{c}X \mathrm{XI} \text { laboratory } \\
\text { strain }\end{array}$ & 0 & 0 & 0 & 0 & 0 & 0 & 0 \\
\hline TMB 3400 & $\begin{array}{l}\text { XR-XDH, } \\
\text { industrial } \\
\text { strain }\end{array}$ & $0.021 \pm 0.013$ & $0.013 \pm 0.01$ & $0.005 \pm 0.001$ & $0.020 \pm 0.012$ & $0.41 \pm 0.02$ & $0.035 \pm 0.006$ & 0 \\
\hline
\end{tabular}



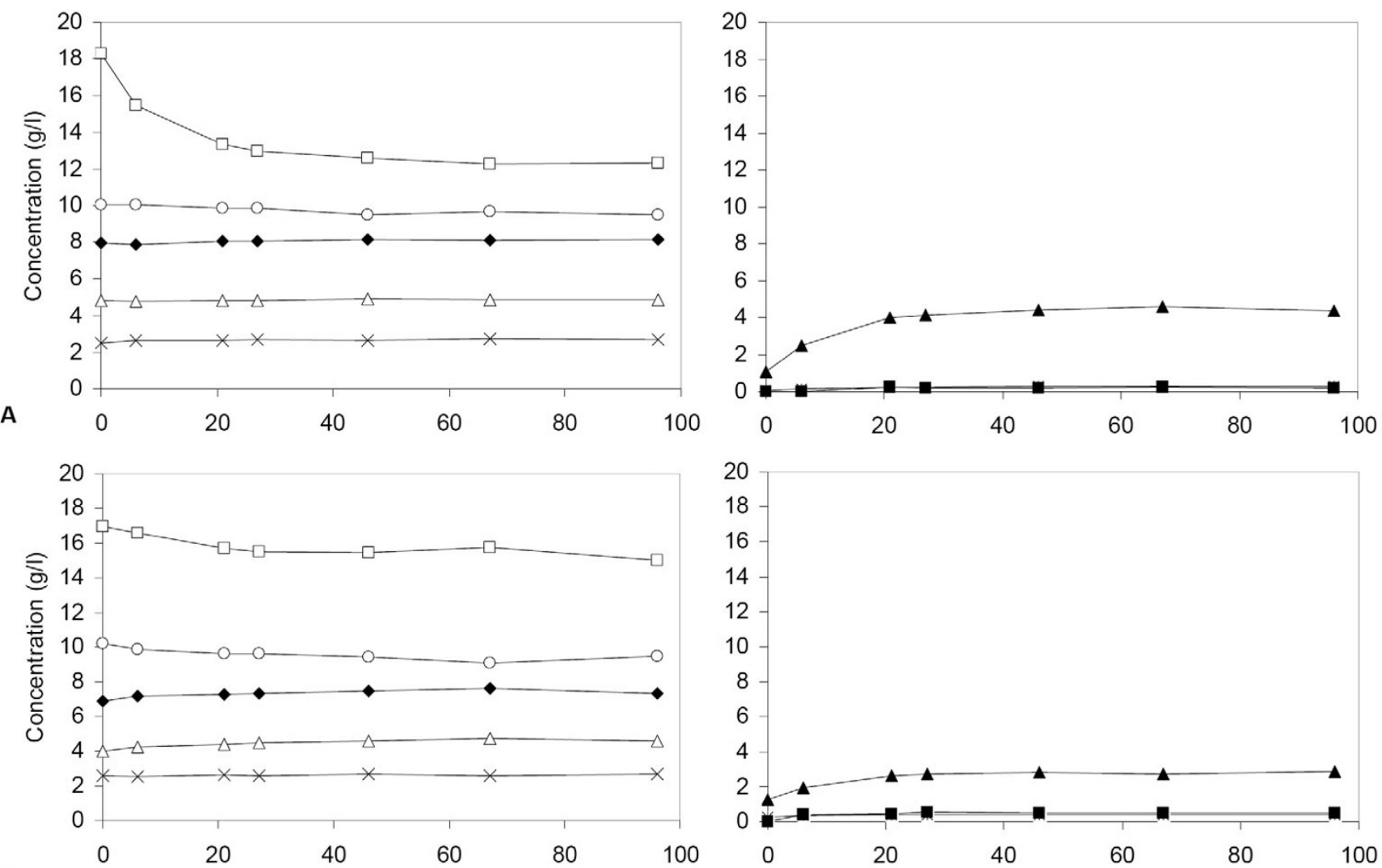

B
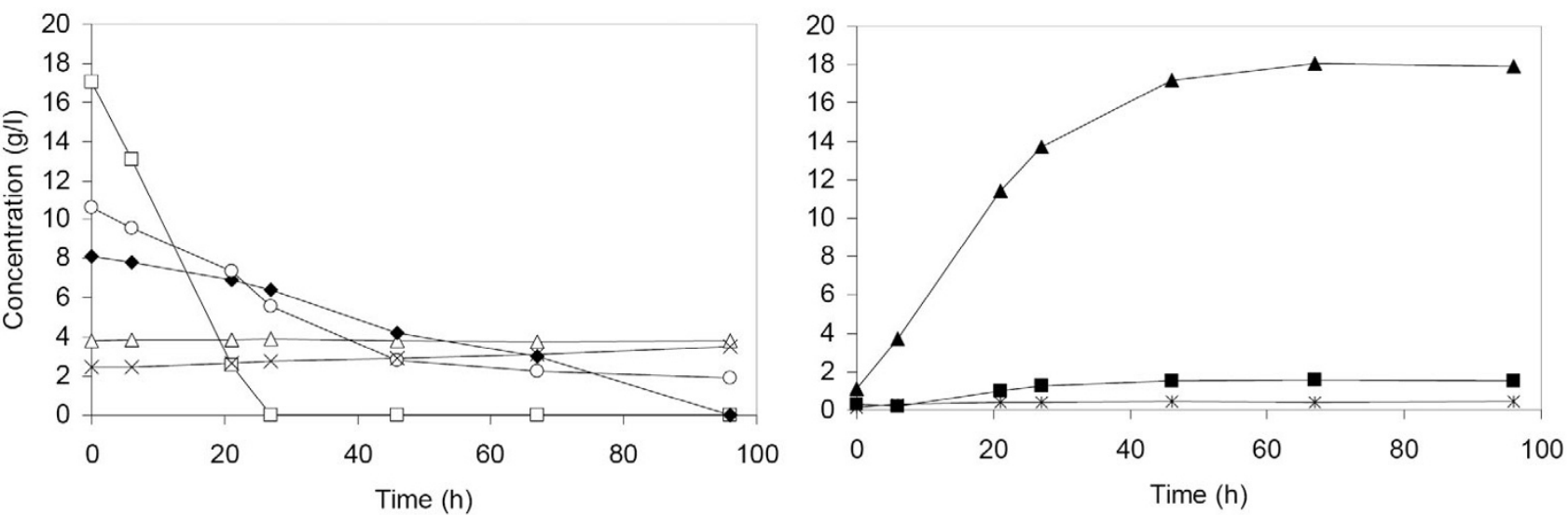

\section{Figure 4}

Fermentation of lignocellulose hydrolysate by strains TMB 3057 (P. stipitis XR and XDH on plasmid) (A), TMB 3066 (Piromyces $\mathrm{XI}$ on plasmid) (B) and TMB 3400 (industrial strain with chromosomally integrated XR and XDH) (C). The initial cell concentration was 5-10 g/l for all the fermentation experiments shown. For clarity, the hydrolysate components and their consumption are shown on the left, and the accumulation of the products is shown on the right. Symbols: $\bigcirc$ mannose; $\square$ glucose; $\Delta$ galactose; $\diamond$ xylose; ${ }^{*}$ xylitol; $\boldsymbol{\square}$ glycerol; $\boldsymbol{\Delta}$ ethanol; $\times$ acetate.

be less tolerant than industrial strains to inhibitory compounds present in lignocellulose hydrolysates $[40,41,56]$. For instance, the industrial strains TMB 3400 and TMB 3000 were shown to retain viability and fermentation capacity in lignocellulosic hydrolysates whereas the labo- ratory strain CBS 8066 did not $[48,57]$. This was confirmed here by the observation that the CEN.PK based laboratory strains of this study did not significantly ferment the investigated undetoxified spruce hydrolysate, whereas the industrial strain TMB 3400 produced ethanol 
Table 4: Comparison of XI and XR-XDH-carrying laboratory strains and the industrial XR-XDH carrying strain TMB 3400.

\begin{tabular}{|c|c|c|c|c|c|c|c|c|c|c|c|c|}
\hline \multirow[b]{2}{*}{ Strain } & \multirow[b]{2}{*}{$\begin{array}{l}\text { Aerobic } \\
\text { growth rate } \\
\text { xylose } h^{-1}\end{array}$} & \multicolumn{2}{|c|}{ Anaerobic fermentation } & \multicolumn{8}{|c|}{ Enzyme activity $\mathrm{U} / \mathrm{mg}$ protein } & \multirow[t]{2}{*}{ Reference } \\
\hline & & $\begin{array}{l}\text { Xylose cons. } \\
\text { rate g xylose g } \\
\text { cells-1 } \mathrm{h}^{-1}\end{array}$ & $\begin{array}{l}\text { Ethanol yield } \\
\text { g ethanol g } \\
\text { consumed sugar-1 }\end{array}$ & $\mathbf{X I}$ & $\mathbf{X R}$ & XDH & $\mathbf{X K}$ & TAL & TKL & RKI & RPE & \\
\hline TMB 3057 & 0.16 & 0.13 & 0.33 & - & 0.35 & 2.16 & $0.89 *$ & $0.91 *$ & $0.06^{*}$ & $0.14^{*}$ & $0.09 *$ & [29] \\
\hline TMB 3066 & 0.02 & 0.05 & 0.43 & 0.82 & - & - & $0.89 *$ & $0.91 *$ & $0.06^{*}$ & $0.14^{*}$ & $0.09 *$ & This work \\
\hline RWB2I7 & 0.22 & $0.50 * *$ & 0.43 & $0.3-1.1$ & - & - & + & + & + & + & + & {$[28]$} \\
\hline TMB 3400 & 0.14 & 0.06 & 0.34 & - & 0.09 & 0.59 & + & $\uparrow$ & $\uparrow$ & n.a. & n.a. & {$[55]$} \\
\hline
\end{tabular}

Aerobic growth rates on xylose, average xylose consumption rate for 50 hours of fermentation, and ethanol yield for anaerobic xylose fermentation are presented together with the enzyme activities of relevant enzymes are presented. (+ overexpressed by genetic engineering; $\uparrow$ upregulated upon mutagenesis).

* Measured for strain background TMB 3044

** Average rate for batch fermentation recalculated from [28] to allow comparison

from most of the sugar present. A slightly higher amount of glucose was consumed by the XR-XDH-carrying laboratory strain TMB 3057 than by the XI-carrying laboratory strain TMB 3066, which may reflect the possible function of the heterologous XR in stress response, similarly to the native aldose reductases in $S$. cerevisiae $[35,58]$.

Nearly all the xylose was consumed by TMB 3400 in the hydrolysate, with ethanol as the main product. No xylitol was produced. The absence of xylitol production in undetoxified lignocellulose hydrolysate is in agreement with previous studies, in which the presence of external electron acceptors such as furfural reduced xylitol formation [59-61]. Absence of xylitol formation has frequently been observed in lignocellulose fermentation with XR- and XDH-carrying strains $[48,49,62-64]$. Indeed, in a comparison of different hydrolysates for fermentability by an XRXDH-carrying strain, xylitol formation was only detected in a corn fiber hydrolysate [49], which is known to contain less furfural than softwood hydrolysates [65].

\section{Conclusion}

When comparing two isogenic strains with high-level expression of the XR-XDH pathway or the XI pathway, higher specific ethanol productivity was observed with the XR-XDH pathway as a result of significantly higher xylose consumption rate in the strain background investigated. On the other hand, the ethanol yield was higher in the XI carrying strain. The CEN.PK-based laboratory strains did not ferment the lignocellulose hydrolysate used in this study, demonstrating that robust industrial strains are essential for the fermentation of industrial substrates. Xylitol formation, which has been often described as being the major drawback of the XR-XDH strategy, was not observed in the fermentation of lignocellulosic hydrolysate by TMB 3400 .

\section{Methods \\ Strains and media}

Plasmids and yeast strains used in this study are summarized in Table 1. Escherichia coli strain DH5a (Life Technologies, Rockville, MD, USA) was used for cloning. E. coli was grown in LB medium [66] supplemented with ampicillin $(100 \mathrm{mg} / \mathrm{l})$. Liquid cultures of $S$. cerevisiae were grown in yeast nitrogen base medium (YNB) (Difco YNB without amino acids $(6.7 \mathrm{~g} / \mathrm{l})$, Becton, Dickinson and Company, Sparks, MD, USA) supplemented with glucose $(20 \mathrm{~g} / \mathrm{l})$ or xylose $(50 \mathrm{~g} / \mathrm{l})$ (Acros Organics, NJ, USA) and buffered at $\mathrm{pH} 5.5$ with potassium hydrogen pththalate $(10.2 \mathrm{~g} / \mathrm{l})$ [37]. YPD or YNB plates were used for plate cultures. When required, the medium was supplemented with uracil $(40 \mu \mathrm{g} / \mathrm{ml})$.

Lignocellulose hydrolysate generated by two-step dilute acid hydrolysis of spruce [44] was used. The hydrolysate was stored at $4^{\circ} \mathrm{C}$ at $\mathrm{pH} 1.5$. Before usage, the $\mathrm{pH}$ was adjusted to 5.5 and the hydrolysate was sterile filtered.

\section{Molecular biology methods and cloning}

Standard molecular biology techniques were used [66]. The calcium chloride method was used for transformation of E. coli [67] and the lithium acetate method was used for transformation of S. cerevisiae [68]. Taq polymerase, restriction enzymes and T4-nucleotide ligase were purchased from Fermentas (Vilnius, Lithuania). DNA sequencing was performed with an Abi-Prism BigDye cycle sequencing kit (Applied Biosystems, Weiterstadt, Germany). 
The gene coding for the Piromyces sp. XI was commercially synthesized and cloned in plasmid YEplacHXT with the restriction enzymes BamHI and PstI. Correct ligation and gene sequence was verified by electrophoresis, PCR and sequencing. The resultant multicopy plasmid YEpHXTXIp was used to transform S. cerevisiae TMB 3044 [29] and transformants were selected for prototrophy on YNB plates containing glucose. The resultant strain was named TMB 3066.

\section{XI activity}

Cells were grown in YNB medium containing xylose and harvested in mid-exponential growth phase. Cells were washed with sterile water and proteins were extracted with yeast protein extract solution Y-PER (Pierce, Rockford, IL, USA) according to the manufacturer's instructions. Protein concentrations were determined with Coomassie protein assay reagent (Pierce) according to the manufacturer's instructions. The XI activity was determined using sorbitol dehydrogenase as previously described [26] at $30^{\circ} \mathrm{C}$. A U2000 spectrophotometer (Hitachi, Tokyo, Japan) was used for the measurements, which were performed for biological triplicate samples.

\section{Growth experiments}

Pre-cultures were cultivated until the late exponential phase in YNB medium with glucose. Cells were inoculated at an initial $\mathrm{OD}_{620 \mathrm{~nm}}$ of 0.2 in YNB medium with xylose $(50 \mathrm{~g} / \mathrm{l})$, and grown in shake flasks at $30^{\circ} \mathrm{C}$ with $200 \mathrm{rpm}$ agitation (INR-200 shake incubator, Gallenkamp, Leicester, UK). Experiments were repeated at least twice.

\section{Batch fermentation}

Pre-cultures were grown until the late exponential growth phase $\left(\mathrm{OD}_{620 \mathrm{~nm}} 20\right)$ in YNB medium with xylose $(50 \mathrm{~g} / \mathrm{l})$. Cells were harvested by centrifugation for 3 minutes at $4{ }^{\circ} \mathrm{C}$, after which the cell pellets were mixed with the fermentation medium. Anaerobic batch fermentation was performed at $30^{\circ} \mathrm{C}$ in $25 \mathrm{ml}$ serum flasks containing 23 $\mathrm{ml}$ medium. The flasks were sealed with rubber stoppers into which cannulas were inserted for sampling and the release of exhaust gas, and were stirred with small magnetic stirrers at $150 \mathrm{rpm}$. A layer of mineral oil was added to ensure anaerobiosis. Samples were withdrawn during 100 hours of fermentation. Experiments were performed at least in duplicate.

For fermentation in mineral medium, YNB medium containing xylose $(50 \mathrm{~g} / \mathrm{l})$ was used, complemented with potassium hydrogen phthalate buffer ( $\mathrm{pH}$ 5.5) [37], Tween $80(0.4 \mathrm{~g} / \mathrm{l})$ and ergosterol $(0.01 \mathrm{~g} / \mathrm{l})$. Lignocellulose hydrolysate was complemented with concentrated YNB, Tween $80(0.4 \mathrm{~g} / \mathrm{l})$ and ergosterol $(0.01 \mathrm{~g} / \mathrm{l})$. The total volume of the added medium components did not exceed $10 \%$ of the culture volume. Tween 80 and ergos- terol were added dissolved in ethanol, which resulted in an initial ethanol concentration of about $1 \mathrm{~g} / \mathrm{l}$, which was taken into account in all calculations. The initial cell concentration was $5 \mathrm{~g}$ dry weight/l for the xylose fermentation and 5-10 g dry weight/l for lignocellulose hydrolysate fermentation.

\section{Analyses}

Concentrations of xylose, xylitol, glycerol, acetic acid and ethanol from fermentation in mineral medium were analysed by HPLC (Waters, Milford, Massachusetts, USA) with an Aminex HPX-87H ion-exchange column (BioRad, Hercules, USA). A mobile phase of $5 \mathrm{mM} \mathrm{H}_{2} \mathrm{SO}_{4}$ was used at a flow rate $0.6 \mathrm{ml} / \mathrm{min}$ and the column temperature was $45^{\circ} \mathrm{C}$. For xylose fermentation experiments, the ethanol concentration was corrected for evaporation with the help of degree of reduction balance calculation. In the case of hydrolysate fermentation, the concentrations of glucose, xylose, galactose, arabinose, glycerol, xylitol and arabitol were analysed with HPLC (Waters, Milford, Massachusetts, USA) using an HPX-87P (Bio-Rad, Hercules, USA) ion exchange column at $85^{\circ} \mathrm{C}$ with water as the mobile phase at a flow rate of $0.5 \mathrm{ml} / \mathrm{min}$. Glucose, galactose, mannose, glycerol, acetic acid and ethanol were analysed by HPLC (Beckman Instruments, Fullerton, CA, USA) using three Aminex HPX-87H ion exchange columns (Bio-Rad, Hercules, USA) connected in series, to allow separation of the peaks. A temperature of $45^{\circ} \mathrm{C}$ and a mobile phase of $5 \mathrm{mM} \mathrm{H}_{2} \mathrm{SO}_{4}$ at a flow rate $0.6 \mathrm{ml} / \mathrm{min}$ were used.

Cell dry weight was determined in triplicate by filtering 1 $\mathrm{ml}$ of the culture with a pre-weighed nitrocellulose filter with $0.45 \mu \mathrm{m}$ pores. Filters were dried in a microwave oven and weighed.

\section{Authors' contributions}

KK participated in the design of the study, performed cloning, strain construction and fermentation experiments, analyzed the data and wrote the manuscript.

RGS participated in design and performance of cloning and strain construction.

BHH participated in design of the study and commented the manuscript.

MFGG participated in design of the study and commented the manuscript.

All authors have read and approved the manuscript.

\section{Acknowledgements}

Maurizio Bettiga is acknowledged for assistance in making the integrative construct and performing enzyme assays. KK was financed by the Swedish Energy Administration. 


\section{References}

I. Hahn-Hägerdal B, Pamment N: Microbial pentose metabolism. Appl Biochem Biotechnol 2004, I I 3-I I 6: I 207-I 209.

2. Hahn-Hägerdal B, Wahlbom CF, Gardonyi M, van Zyl WH, Cordero Otero RR, Jönsson LJ: Metabolic engineering of Saccharomyces cerevisiae for xylose utilization. Adv Biochem Eng Biotechnol 200 I, 73:53-84.

3. von Sivers $M$, Zacchi G: Ethanol from lignocellulosics: a review of the economy. Biores Technol 1996, 56:|3|-|40.

4. Kötter P, Amore R, Hollenberg CP, Ciriacy M: Isolation and characterization of the Pichia stipitis xylitol dehydrogenase gene, XYL2, and construction of a xylose-utilizing Saccharomyces cerevisiae transformant. Curr Genet 1990, 18:493-500.

5. Ho NW, Chen Z, Brainard AP: Genetically engineered Saccharomyces yeast capable of effective cofermentation of glucose and xylose. Appl Environ Microbiol 1998, 64:1852-1859.

6. Eliasson A, Christensson C, Wahlbom CF, Hahn-Hägerdal B: Anaerobic xylose fermentation by recombinant Saccharomyces cerevisiae carrying XYLI, XYL2, and XKSI in mineral medium chemostat cultures. Appl Environ Microbiol 2000, 66:338I-3386.

7. Tantirungkij M, Nakashima N, Seki T, Yoshida T: Construction of xylose-assimilating Saccharomyces cerevisiae. J Ferment Bioeng 1993, 75:83-88.

8. Toivari MH, Aristidou A, Ruohonen L, Penttilä M: Conversion of xylose to ethanol by recombinant Saccharomyces cerevisiae: importance of xylulokinase (XKSI) and oxygen availability. Metab Eng 200I, 3:236-249.

9. Bruinenberg PM, de Bot PHM, van Dijken JP, Scheffers WA: NADHlinked aldose reductase: the key to anaerobic fermentation of xylose by yeasts. Appl Microbiol Biotechnol 1984, 19:256-260.

10. Bruinenberg PM, Peter HM, van Dijken JP, Scheffers WA: The role of redox balances in the anaerobic fermentation of xylose by yeasts. Eur J Appl Microb Biotech 1983, I 8:287-292.

I I. Kötter P, Ciriacy M: Xylose fermentation by Saccharomyces cerevisiae. Appl Microbiol Biotechnol 1993, 38:776-783.

12. Walfridsson M, Anderlund M, Bao X, Hahn-Hägerdal B: Expression of different levels of enzymes from the Pichia stipitis XYLI and XYL2 genes in Saccharomyces cerevisiae and its effects on product formation during xylose utilisation. Appl Microbiol Biotechnol 1997, 48:218-224.

13. Eliasson A, Hofmeyr JHS, Pedler S, Hahn-Hägerdal B: The xylose reductase/xylitol dehydrogenase/xylulokinase ratio affects product formation in recombinant xylose-utilising Saccharomyces cerevisiae. Enzyme Microb Technol 200I, 29:288-297.

14. Jin YS, Jeffries TW: Changing flux of xylose metabolites by altering expression of xylose reductase and xylitol dehydrogenase in recombinant Saccharomyces cerevisiae. Appl Biochem Biotechnol 2003, 105 - I 08:277-286.

15. Karhumaa K, Fromanger R, Hahn-Hägerdal B, Gorwa-Grauslund MF: High activity of xylose reductase and xylitol dehydrogenase improves xylose fermentation by recombinant Saccharomyces cerevisiae. Appl Microbiol Biotechnol 2007, 73:I039-I046.

16. Jeppsson M, Bengtsson O, Franke K, Lee H, Hahn-Hägerdal B, GorwaGrauslund MF: The expression of a Pichia stipitis xylose reductase mutant with higher $\mathrm{K}(\mathrm{M})$ for NADPH increases ethanol production from xylose in recombinant Saccharomyces cerevisiae. Biotechnol Bioeng 2006, 93:665-673.

17. Jeppsson M, Johansson B, Hahn-Hägerdal B, Gorwa-Grauslund MF: Reduced oxidative pentose phosphate pathway flux in recombinant xylose-utilizing Saccharomyces cerevisiae strains improves the ethanol yield from xylose. Appl Environ Microbiol 2002, 68:1604-1609.

18. Verho R, Londesborough J, Penttilä M, Richard P: Engineering redox cofactor regeneration for improved pentose fermentation in Saccharomyces cerevisiae. Appl Environ Microbiol 2003, 69:5892-5897.

19. Roca C, Nielsen J, Olsson L: Metabolic engineering of ammonium assimilation in xylose-fermenting Saccharomyces cerevisiae improves ethanol production. Appl Environ Microbiol 2003, 69:4732-4736.

20. Sarthy AV, McConaughy BL, Lobo Z, Sundstrom JA, Furlong CE, Hall $\mathrm{BD}$ : Expression of the Escherichia coli xylose isomerase gene in Saccharomyces cerevisiae. Appl Environ Microbiol 1987, 53:1996-2000.

21. Amore R, Wilhelm M, Hollenberg CP: The fermentation of xylose - an analysis of the expression of Bacillus and Actinoplanes xylose isomerase genes in yeast. Appl Microbiol Biotechnol 1989, 30:351-357

22. Briggs KA, Lancashire WE, Hartley BS: Molecular cloning, DNA structure and expression of the Escherichia coli D-xylose isomerase. Embo J 1984, 3:6 I I-6I6.

23. Gárdonyi M, Hahn-Hägerdal B: The Streptomyces rubiginosus xylose isomerase is misfolded when expressed in Saccharomyces cerevisiae. Enzyme Microb Technol 2003, 32:252-259.

24. Moes CJ, Pretorius IS, van Zyl C: Cloning and expression of the Clostridium thermosulfurogenes D-xylose isomerase gene (xyIA) in Saccharomyces cerevisiae. Biotech Lett 1996, I 8:269-274.

25. Walfridsson M, Bao X, Anderlund M, Lilius G, Bulow L, Hahn-Hägerdal B: Ethanolic fermentation of xylose with Saccharomyces cerevisiae harboring the Thermus thermophilus xylA gene, which expresses an active xylose (glucose) isomerase. Appl Environ Microbiol 1996, 62:4648-465I.

26. Kuyper M, Harhangi HR, Stave AK, Winkler AA, Jetten MS, de Laat WT, den Ridder JJ, Op den Camp HJ, van Dijken JP, Pronk JT: Highlevel functional expression of a fungal xylose isomerase: the key to efficient ethanolic fermentation of xylose by Saccharomyces cerevisiae? FEMS Yeast Res 2003, 4:69-78.

27. Kuyper M, Winkler AA, Van Dijken JP, Pronk JT: Minimal metabolic engineering of Saccharomyces cerevisiae for efficient anaerobic xylose fermentation: a proof of principle. FEMS Yeast Res 2004, 4:655-664.

28. Kuyper M, Hartog MM, Toirkens MJ, Almering MJ, Winkler AA, van Dijken JP, Pronk JT: Metabolic engineering of a xylose-isomerase-expressing Saccharomyces cerevisiae strain for rapid anaerobic xylose fermentation. FEMS Yeast Res 2005, 5:399-409.

29. Karhumaa K, Hahn-Hägerdal B, Gorwa-Grauslund MF: Investigation of limiting metabolic steps in the utilization of xylose by recombinant Saccharomyces cerevisiae using metabolic engineering. Yeast 2005, 22:359-368.

30. Ho NW, Chang SF: Cloning of yeast xylulokinase gene by complementation of $\boldsymbol{E}$. coli and yeast mutations. Enzyme Microb Technol 1989, I I:4 I7-42I.

31. Rodriguez-Pena JM, Cid VJ, Arroyo J, Nombela C: The YGRI94c (XKSI) gene encodes the xylulokinase from the budding yeast Saccharomyces cerevisiae. FEMS Microbiol Lett 1998, 162:155-160.

32. Johansson B, Hahn-Hägerdal B: The non-oxidative pentose phosphate pathway controls the fermentation rate of xylulose but not of xylose in Saccharomyces cerevisiae TMB300 I. FEMS Yeast Res 2002, 2:277-282.

33. Kuhn A, van Zyl C, van Tonder A, Prior BA: Purification and partial characterization of an aldo-keto reductase from Saccharomyces cerevisiae. Appl Environ Microbiol I995, 6 I : I580- I585.

34. Träff KL, Otero Cordero RR, van Zyl WH, Hahn-Hägerdal B: Deletion of the GRE3 aldose reductase gene and its influence on xylose metabolism in recombinant strains of Saccharomyces cerevisiae expressing the xyIA and XKSI genes. Appl Environ Microbiol 200I, 67:5668-5674.

35. Träff-Bjerre KL, Jeppsson M, Hahn-Hägerdal B, Gorwa-Grauslund MF: Endogenous NADPH-dependent aldose reductase activity influences product formation during xylose consumption in recombinant Saccharomyces cerevisiae. Yeast 2004, 2 I : | 4 | - I 50.

36. Yamanaka K: Inhibition of D-xylose isomerase by pentitols and D-lyxose. Arch Biochem Biophys 1969, I 3 I:502-506.

37. Hahn-Hägerdal B, Karhumaa K, Larsson CU, Gorwa-Grauslund M, Görgens J, van Zyl WH: Role of cultivation media in the development of yeast strains for large scale industrial use. Microb Cell Fact 2005, 4:31.

38. Almeida JR, Modig T, Petersson A, Hahn-Hägerdal B, Liden G, GorwaGrauslund MF: Increased tolerance and conversion of inhibitors in lignocellulosic hydrolysates by Saccharomyces cerevisiae. in press.

39. Liu ZL: Genomic adaptation of ethanologenic yeast to biomass conversion inhibitors. Appl Microbiol Biotechnol 2006, 73:27-36

40. Nilsson A, Gorwa-Grauslund MF, Hahn-Hägerdal B, Liden G: Cofactor dependence in furan reduction by Saccharomyces cerevisiae in fermentation of acid-hydrolyzed lignocellulose. Appl Environ Microbiol 2005, 71 :7866-787I.

4I. Sonderegger M, Jeppsson M, Larsson C, Gorwa-Grauslund MF, Boles E, Olsson L, Spencer-Martins I, Hahn-Hägerdal B, Sauer U: Fermen- 
tation performance of engineered and evolved xylose-fermenting Saccharomyces cerevisiae strains. Biotechnol Bioeng 2004, 87:90-98.

42. Wahlbom CF, van Zyl WH, Jönsson LJ, Hahn-Hägerdal B, Otero RR: Generation of the improved recombinant xylose-utilizing Saccharomyces cerevisiae TMB 3400 by random mutagenesis and physiological comparison with Pichia stipitis CBS 6054. FEMS Yeast Res 2003, 3:319-326.

43. Hauf J, Zimmermann FK, Muller S: Simultaneous genomic overexpression of seven glycolytic enzymes in the yeast Saccharomyces cerevisiae. Enzyme Microb Technol 2000, 26:688-698.

44. Larsson S, Cassland P, Jönsson LJ: Development of a Saccharomyces cerevisiae strain with enhanced resistance to phenolic fermentation inhibitors in lignocellulose hydrolysates by heterologous expression of laccase. Appl Environ Microbiol 200I, 67:1163-1170.

45. Bothast RJ, Nichols NN, Dien BS: Fermentations with new recombinant organisms. Biotechnol Prog 1999, I5:867-875.

46. Zhang Z, Moo-Young M, Chisti Y: Plasmid stability in recombinant Saccharomyces cerevisiae. Biotechnol Adv 1996, | 4:40|-435

47. Ugolini S, Tosato V, Bruschi CV: Selective fitness of four episomal shuttle-vectors carrying HIS3, LEU2, TRPI, and URA3 selectable markers in Saccharomyces cerevisiae. Plasmid 2002, 47:94-107.

48. Öhgren K, Bengtsson O, Gorwa-Grauslund MF, Galbe M, Hahn-Hägerdal B, Zacchi G: Simultaneous saccharification and co-fermentation of glucose and xylose in steam-pretreated corn stover at high fiber content with Saccharomyces cerevisiae TMB3400. J Biotechnol 2006, doi 10.1016/j.jbiotec.2006.05.001:

49. Sedlak M, Ho NW: Production of ethanol from cellulosic biomass hydrolysates using genetically engineered Saccharomyces yeast capable of cofermenting glucose and xylose. Appl Biochem Biotechnol 2004, I I 3-I I 6:403-4I6.

50. Verduyn C, Van Kleef R, Frank J, Schreuder H, Van Dijken JP, Scheffers WA: Properties of the NAD(P)H-dependent xylose reductase from the xylose-fermenting yeast Pichia stipitis. Biochem J 1985, 226:669-677.

51. Rizzi M, Elrlemann P, Bui-Thahn NA, Dellweg H: Xylose fermentation by yeasts. 4. Purification and kinetic studies of xylose reductase from Pichia stipitis. Appl Microbiol Biotechnol 1988, 29:| $148-154$.

52. http://www.brenda.uni-koeln.del.

53. Lönn A, Gardonyi M, van ZyI W, Hahn-Hägerdal B, Otero RC: Cold adaptation of xylose isomerase from Thermus thermophilus through random PCR mutagenesis. Gene cloning and protein characterization. Eur J Biochem 2002, 269:157-163.

54. Stemmer WP: Rapid evolution of a protein in vitro by DNA shuffling. Nature 1994, 370:389-391.

55. Wahlbom CF, Cordero Otero RR, van Zyl WH, Hahn-Hägerdal B, Jönsson LJ: Molecular analysis of a Saccharomyces cerevisiae mutant with improved ability to utilize xylose shows enhanced expression of proteins involved in transport, initial xylose metabolism, and the pentose phosphate pathway. Appl Environ Microbiol 2003, 69:740-746.

56. Garay-Arroyo A, Covarrubias AA, Clark I, Nino I, Gosset G, Martinez $A$ : Response to different environmental stress conditions of industrial and laboratory Saccharomyces cerevisiae strains. Appl Microbiol Biotechnol 2004, 63:734-74I.

57. Rudolf $A$, Galbe $M$, Liden $G$ : Controlled fed-batch fermentations of dilute-acid hydrolysate in pilot development unit scale. Appl Biochem Biotechnol 2004, I I 3-1 | 6:60 I-6 I7.

58. Chang Q, Harter TM, Rikimaru LT, Petrash JM: Aldo-keto reductases as modulators of stress response. Chem Biol Interact 2003, 143-144:325-332.

59. Alexander $\mathrm{NJ}$ : Acetone stimulation of ethanol production from D-xylose by Pachysolen tannophilus. Appl Microbiol Biotechnol 1986, 25:203-207.

60. Ligthelm ME, Prior BA, du Preez JC: Effect of hydrogen acceptors on D-xylose fermentation by anaerobic culture of immobilized Pachysolen tannophilus cells. Biotechnol Bioeng 1989, 32:839-844.

6I. Wahlbom CF, Hahn-Hägerdal B: Furfural, 5-hydroxymethyl furfural, and acetoin act as external electron acceptors during anaerobic fermentation of xylose in recombinant Saccharomyces cerevisiae. Biotechnol Bioeng 2002, 78: 172-178.
62. Martin C, Galbe M, Wahlbom CF, Hahn-Hägerdal B, Jönsson L): Ethanol production from enzymatic hydrolysates of sugarcane bagasse using recombinant xylose-utilising Saccharomyces cerevisiae. Enzyme Microb Technol 2002, 3 I :274-282.

63. Moniruzzaman M, Dien BS, Skory CD, Chen ZD, Hespell RB, Ho $N W$, Dale BE, Bothast RJ: Fermentation of corn fibre sugars by an engineered xylose utilizing Saccharomyces yeast strain. World J Microb Biotechnol 1998, 13:341-346.

64. Katahira S, Mizuike A, Fukuda H, Kondo A: Ethanol fermentation from lignocellulosic hydrolysate by a recombinant xyloseand cellooligosaccharide-assimilating yeast strain. Appl Microbiol Biotechnol 2006, doi 10.1007/s00253-006-0402-x:

65. Klinke HB, Thomsen AB, Ahring BK: Inhibition of ethanol-producing yeast and bacteria by degradation products produced during pre-treatment of biomass. Appl Microbiol Biotechnol 2004, 66: 10-26.

66. Sambrook J, Fritch E, Maniatis T: Molecular cloning: a laboratory manual. 2nd ed. Cold Spring Harbor, NY, Cold Spring Harbor Laboratory Press; 1989.

67. Dagert M, Ehrlich SD: Prolonged incubation in calcium chloride improves the competence of Escherichia coli cells. Gene 1979 , 6:23-28.

68. Gietz RD, Schiestl RH, Willems AR, Woods RA: Studies on the transformation of intact yeast cells by the LiAc/SS-DNA/ PEG procedure. Yeast 1995, I I:355-360.

Publish with Bio Med Central and every scientist can read your work free of charge

"BioMed Central will be the most significant development for disseminating the results of biomedical research in our lifetime. "

Sir Paul Nurse, Cancer Research UK

Your research papers will be:

- available free of charge to the entire biomedical community

- peer reviewed and published immediately upon acceptance

- cited in PubMed and archived on PubMed Central

- yours - you keep the copyright

Submit your manuscript here:

http://www.biomedcentral.com/info/publishing_adv.asp
BioMedcentral 